\title{
Invasion risks posed by the aquarium trade and live fish markets on the Laurentian Great Lakes
}

\author{
CORINNE A.M. RIXON ${ }^{1}$, IAN C. DUGGAN ${ }^{1, *}$, NATHALIE M.N. \\ BERGERON $^{1}$, ANTHONY RICCIARDI ${ }^{2}$ and HUGH J. MACISAAC ${ }^{1}$ \\ ${ }^{1}$ Great Lakes Institute for Environmental Research, University of Windsor, 401 Sunset Ave., Windsor, \\ Ontario, Canada N9B 3P4; ${ }^{2}$ Redpath Museum, McGill University, 859 Sherbrooke St. West, Montréal, \\ Québec, Canada H3A 2K6; *Author for correspondence (e-mail: i.duggan@waikato.ac.nz)
}

Received 21 August 2003; accepted in revised form 14 January 2004

Key words: Alternative vectors, Aquaria, Biological invasion, Live food fish, Ornamental, Predicting invaders, Risk assessment

\begin{abstract}
International trade is an important mechanism for global non-indigenous species introductions, which have had profound impacts on the biodiversity of aquatic ecosystems including the Laurentian Great Lakes. The best-documented vector by which non-indigenous species have entered the Great Lakes is ballast water discharged by transoceanic ships. A variety of potential alternative vectors exist, including the intentional release of aquarium or food organisms. To assess whether these vectors pose a significant invasion risk for the Great Lakes, we surveyed fish sold live in markets and fish, mollusks and macrophytes sold in pet and aquarium stores within the Great Lakes watershed. We evaluated invasion risk using information on species' thermal tolerance, history of invasion elsewhere, and potential propagule loads as indicated by frequency of occurrence in shops. Our research suggests that both the aquarium industry and live fish markets represent potential sources of future invaders to the Great Lakes, including several aquarium fishes and macrophytes, as well as Asian carp species sold in fish markets. Currently, few regulatory mechanisms exist to control these potential vectors.
\end{abstract}

\section{Introduction}

The most important pathway for non-indigenous species introductions into North America has been from intentional or unintentional importation of organisms associated with international trade (e.g., Jenkins 1996). The dominant vector for the introduction of non-indigenous species into the Laurentian Great Lakes is by ballast water discharge from transoceanic shipping vessels (Ricciardi and MacIsaac 2000). This vector has historically accounted for approximately $30 \%$ of total introductions, although since 1970 its importance increased to greater than 75\% (Mills et al. 1993; MacIsaac 1999; Ricciardi and MacIsaac 2000). Release of organisms by other vectors, for example, through the aquarium trade, aquaculture industry and cultivation, has also resulted in non-indigenous species introductions to the Great Lakes (Mills et al. 1993). However, vectors other than ballast water have received far less attention despite being potentially easier to regulate.

The aquarium hobby is extremely popular in North America, with over 10\% of households possessing ornamental fish (Ramsey 1985; Chapman et al. 1997). This 
industry has transferred thousands of fish, plant and mollusk species from their native habitats into North America (Courtenay 1999). Freshwater species constitute $96 \%$ of the volume of fish imported (Chapman et al. 1997); thus lakes and rivers appear particularly vulnerable to invasion from this vector. Approximately 100 species of ornamental fishes have been recorded as introduced into North American natural waters via the aquarium trade, of which up to 40 have established populations (Courtenay and Stauffer 1990; Fuller et al. 1999; Crossman and Cudmore 1999a). Eight mollusk species may also have established populations by means of this vector (Mackie 1999). These introductions have typically occurred either by escape from culture facilities or by deliberate release from aquarists seeking to humanely dispose of unwanted pets (Courtenay and Taylor 1986; Courtenay and Stauffer 1990). Establishment or subsequent spread of species in the Great Lakes has included at least four fish, four mollusk, and three plant species.

Another vector with the potential for introduction of non-indigenous species into the Great Lakes is the sale of live fish for human consumption. Freshwater eels (Anguilla species) and northern snakehead (Channa argus) have been introduced into California and Maryland, respectively, by this vector (McCosker 1989; United States Geological Survey website http://nas.er.usgs.gov/). In Canada, live fish are primarily imported from fish farms in the southern United States into the greater Toronto area, and mainly service the local Asian population (Crossman and Cudmore 1999b; Goodchild 1999a). Currently, more than 700,000 kg of live freshwater fish are imported into Ontario annually (Goodchild 1999a), and some live fish might be bought specifically to release for cultural or religious reasons (Severinghaus and Chi 1999). In southeast Asia, carp species are commonly used in prayer release (Severinghaus and Chi 1999). A live bighead carp (Aristichthys nobilis) discovered in a fountain pool in downtown Toronto was most likely purchased from a nearby live fish market (Crossman and Cudmore 1999b).

Consideration has typically been given to non-indigenous species only after they establish in a recipient region. Once a species becomes established, however, eradication is challenging if not impossible (Myers et al. 2000). In order to prevent future invasions in the Great Lakes, and elsewhere, it is important to identify highrisk species and the mechanisms that transport them. Predictive models have been developed for the Great Lakes by Ricciardi and Rasmussen (1998), MacIsaac (1999) and Kolar and Lodge (2002). Ricciardi and Rasmussen's (1998) model uses three simple criteria chosen based on trends identified from previously successful invasions: dominant geographical donor regions and dispersal vectors; biological attributes of invasive species (e.g., the possession of wide environmental tolerances, broad diets and high reproductive capacities); and an invasion history elsewhere in the world. Kolar and Lodge (2002) developed quantitative models to predict potential fish invaders to the Great Lakes based solely on biological characteristics of successful and failed invaders.

In this study, we use Ricciardi and Rasmussen's (1998) approach to determine the invasion risk to the Great Lakes posed by fishes, mollusks and macrophytes sold through the aquarium trade and live fish markets. We also assess and compare the 
probability of fish species establishment from each industry using Kolar and Lodge's (2002) model.

\section{Methods}

\section{Predicting potential invaders}

We modified Ricciardi and Rasmussen's (1998) model to predict invasions by the aquarium trade and live fish markets. In our study, we identified a donor pool of species provided by the aquarium trade and live fish markets, and assumed a vector of deliberate human release. Our primary biological criterion for potential invaders was tolerance to cold temperatures, based on the assumption that the over-wintering ability of introduced species is an important pre-requisite for their establishment in the Great Lakes. Survivorship below $5.5^{\circ} \mathrm{C}$ was our temperature criterion for fish, following Kolar and Lodge (2002). For plants, we used the over-wintering ability imparted by structures such as turions and over-wintering buds, as well as temperature tolerance of the vegetative plant, as criteria to determine whether they could survive in harsh winter climates.

The third criterion used to forecast potential invaders was a history of invasion elsewhere in the world (Reichard and Hamilton 1997; Ricciardi and Rasmussen 1998). Our fourth criterion was 'propagule pressure', a measure of the number of individuals released, which is correlated with establishment success (Williamson 1996; Rouget and Richardson 2003). Based on the assumption that popular species have more opportunities to be released, we used the frequency of occurrence in aquarium stores or live fish markets as a proxy for propagule pressure. Fish, macrophytes and mollusks present in less than $20 \%$ of the stores surveyed were arbitrarily classified as having a low chance of establishing populations, while those species present in $20 \%$ or more of the stores were classified as high risk invaders.

For fish from the aquarium and live food industries, we also used the model of Kolar and Lodge (2002) to predict species that could potentially establish populations. We compared the resulting species with those obtained using our derived model (Figure 1).

\section{Data collection and analysis}

Between October 2002 and July 2003, 20 aquarium and pet stores were visited, ranging from small, privately owned establishments to larger, North American chains. All stores were located in close proximity to Lakes Erie and Ontario, in the following localities: Macomb County (Michigan, USA), and Windsor, Belle River, Leamington, Guelph, Elgin, St. Thomas, Kitchener, and Toronto (Ontario, Canada). The scientific and/or common names of freshwater fish, mollusks and macrophytes were recorded at each location. When a species identity was uncertain, verification 
(a)

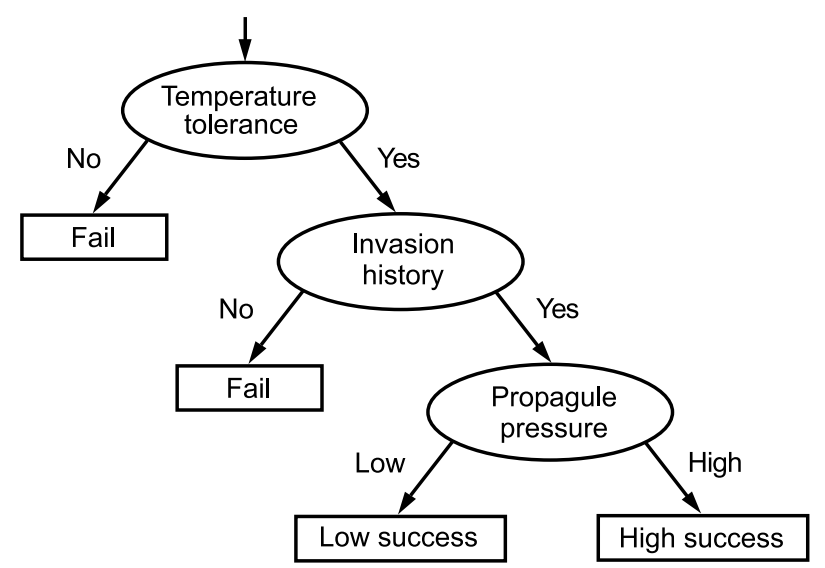

(b)

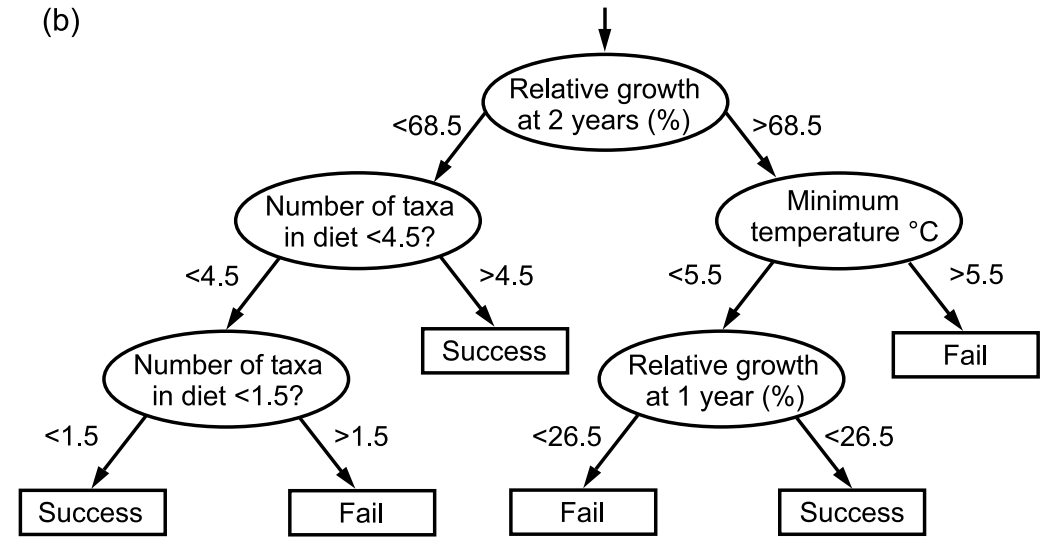

Figure 1. Schematic diagram showing invasion filters (a) modified from Ricciardi and Rasmussen (1998), and (b) developed by Kolar and Lodge (2002). Invasion filters represent sequential stages of the invasion process through which a species must successfully pass if it is to pose an invasion risk to the Great Lakes.

was accomplished after purchasing individuals, or a detailed description of the organism was recorded.

Six live fish markets were visited in Toronto and Windsor (Ontario) and Montréal (Québec) between October 2002 and July 2003. Species present in each store were recorded as per the aquarium stores, and were typically bought for identification. We verified that fish could be purchased and removed from the premises alive. The common names of fishes, provided on their tanks for each species by the proprietors, were also recorded. Fish, macrophyte and mollusk species were identified primarily using Clarke (1981), Page and Burr (1991), Mills (1993), Baensch and Riehl (1996) and Hiscock (2003). Temperature tolerances of each species, as well as their invasion histories, were obtained through literature review or by internet 
search. Fuller et al. (1999) and www.fishbase.org (Froese and Pauly 2002) served as the primary fish references.

\section{Results}

Aquarium trade

We recorded 308 freshwater fish species belonging to 50 families from the 20 stores visited. The mean number of species recorded per store was 62.6 (s.d. $=22.7)$. The most common fish recorded in our survey were goldfish (100\% occurrence), followed by bettas, guppies and neon tetras (each at 95\% occurrence) (Table 1). Based on known temperature tolerances, only seven recorded species could potentially survive winter temperatures in the Great Lakes. Of these, the channel catfish (Ictalurus punctatus) and fathead minnow (Pimephales promelas) are native to the Great Lakes region, and were eliminated from our list of potential invaders. However, we acknowledge that individuals in the aquarium trade may have originated from populations outside the Great Lakes basin and gene pool, raising the possibility of introgression (Fuller et al. 1999). The goldfish (Carassius auratus) and koi carp (Cyprinus carpio) are ornamental species that have already invaded, and are widely distributed in, the Great Lakes; their successful prediction lends confidence to our model. Both of these fish can tolerate low temperatures $\left(<3{ }^{\circ} \mathrm{C}\right)$, have extensive invasion histories, and were present in a high proportion (100 and $85 \%$, respectively) of the stores visited. Three other fishes, all Cypriniformes, were predicted to be potential invaders: Oriental weatherfish (Misgurnus anguillicaudatus), weather loach (Misgurnus fossilis) and white cloud mountain minnow (Tanichthys albonubes).

We could find sufficient data for only 27 of the 306 non-indigenous aquarium fish by literature and internet searches to test using Kolar and Lodge's (2002) model (Figure 1b). An absence of available growth rate data prevented inclusion of more species in the test. Of the 27 species, eight were predicted by Kolar and Lodge's model to succeed if introduced: clown loach (Botia macrocanthus), red tail botia (Botia modesta), oriental weatherfish, goldfish, koi carp, arrowana (Osteoglossum bicirrhosum), giant or red snakehead (Channa micropeltes) and ghost catfish (Kryptopterus bicirrhis).

Four mollusk species from two families were recorded for sale from a subset of ten aquarium and pet stores (Table 2). The mean number of species recorded per store was 1.6 (s.d. = 1.3). None of the three Ampullarids would likely survive Great Lakes winter temperatures, and the Oriental mystery snail has already invaded this system. A number of additional snail species were observed associated with macrophytes or other substrates in aquaria that were not specifically intended for sale. These included Helisoma spp., Micromenetus sp. (Family Planorbidae), Elimia floridensis (Family Pleuroceridae), Melanoides tuberculata (Family Thiaridae) and Physa sp. (Family Physidae). Because these taxa were not intended for sale, and their observation commonly required close examination of each of the tanks due to small size or being hidden amongst macrophytes and substrate, we did not include these in our survey and analyses. 


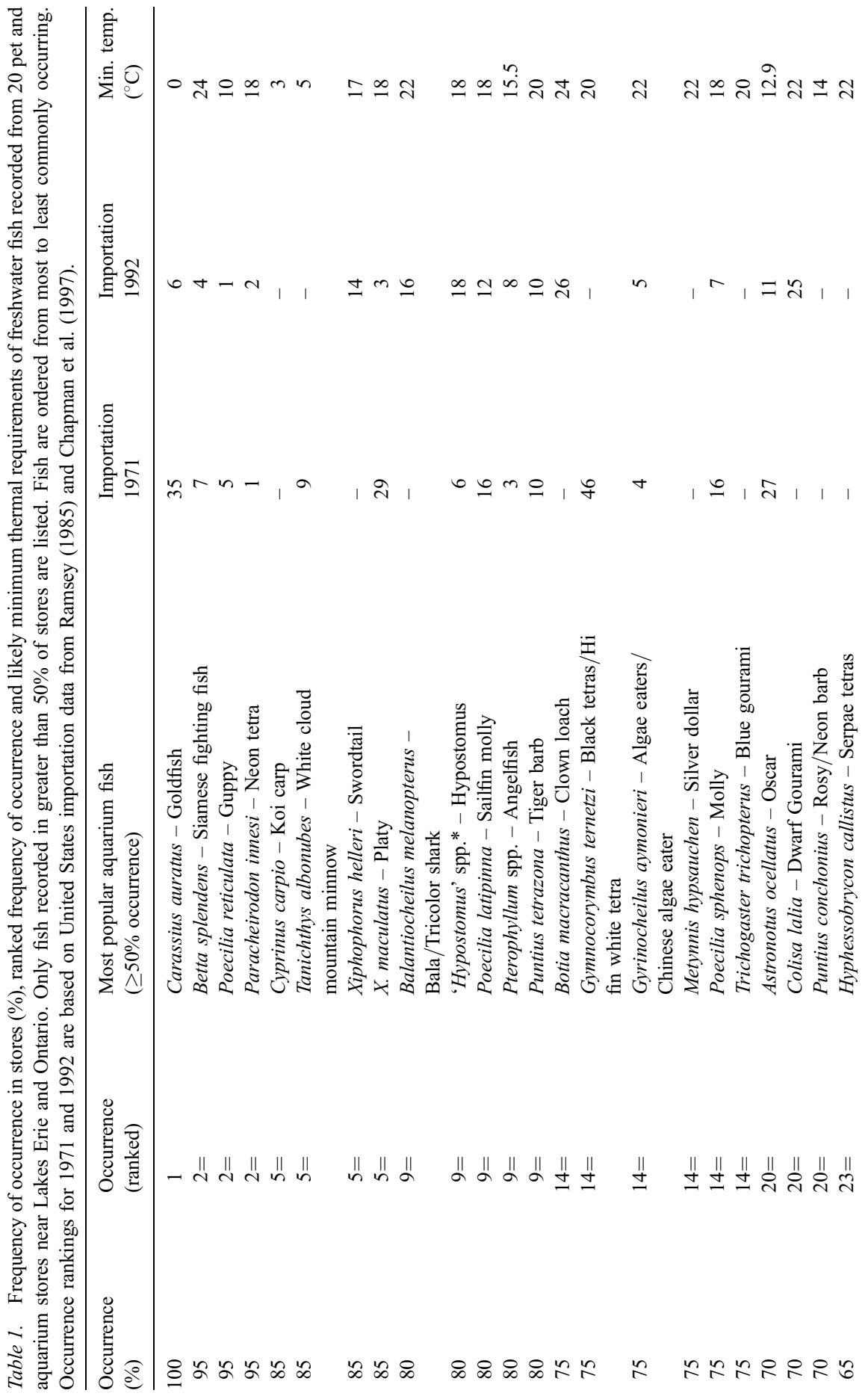




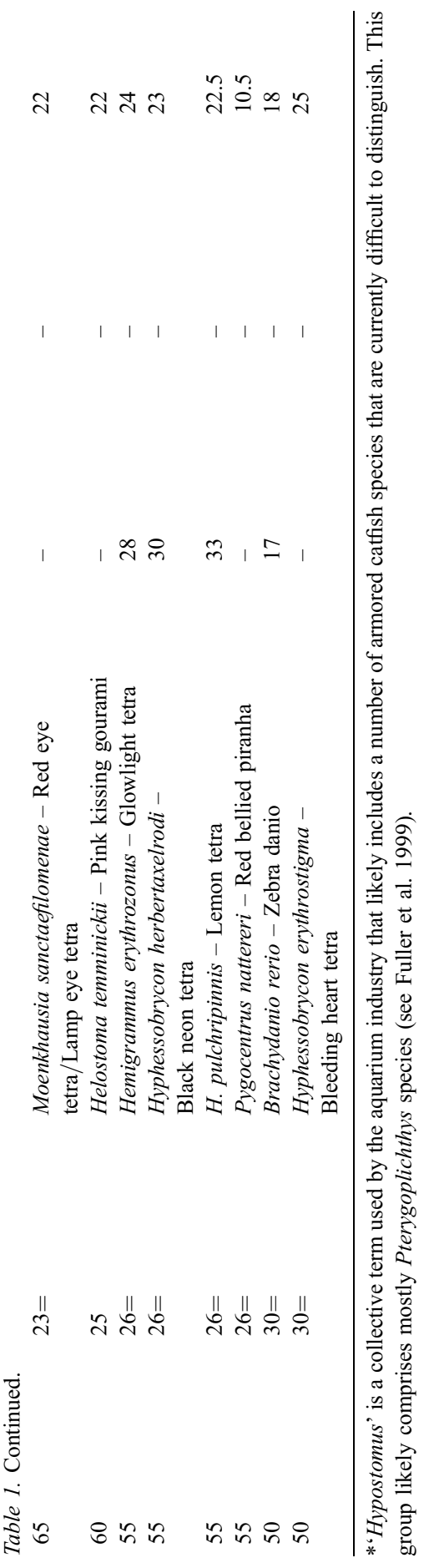


Table 2. Frequency of occurrence in stores (\%), ranked frequency of occurrence and over-wintering ability of freshwater mollusk and macrophyte species recorded from 10 and 20 pet and aquarium stores, respectively, near Lakes Erie and Ontario. Mollusk and macrophyte species are ordered from most to least commonly occurring. Species native to the Great Lakes are marked with an asterisk. Only macrophytes recorded in greater than $20 \%$ of stores are listed.

\begin{tabular}{|c|c|c|c|}
\hline Occurrence $(\%)$ & $\begin{array}{l}\text { Occurrence } \\
\text { (ranked) }\end{array}$ & Species & $\begin{array}{l}\text { Potential to } \\
\text { overwinter }\end{array}$ \\
\hline \multicolumn{4}{|l|}{ Mollusks } \\
\hline 70 & 1 & Pomacea bridgesi - Apple snail & No \\
\hline 60 & 2 & P. canaliculata - Apple snail & No \\
\hline 20 & 3 & Marisa cornuarietis - Columbian ramshorn & No \\
\hline 10 & 4 & $\begin{array}{l}\text { Cipangopaludina chinensis - Oriental } \\
\text { mystery snail }\end{array}$ & Yes \\
\hline \multicolumn{4}{|l|}{ Macrophytes } \\
\hline 40 & 1 & Echinodorus amazonicus - Amazon sword & No \\
\hline 35 & 2 & Egeria densa - Anacharis & Yes \\
\hline 30 & $3=$ & Ceratophyllum demersum - Hornwort* & Yes \\
\hline 30 & $3=$ & Crinum thaianum - Onion plant & No \\
\hline 30 & $3=$ & Eichornia crassipes - Water hyacinth & No \\
\hline 30 & $3=$ & Vallisneria americana - Water celery* & Yes \\
\hline 25 & $7=$ & Hygrophila polysperma - Dwarf hygrophila & Yes \\
\hline 25 & $7=$ & Ludwigia sp. - Red Ludwigia & No \\
\hline 25 & $7=$ & Microsorium pteropus - Java fern & No \\
\hline 25 & $7=$ & Myriophyllum aquaticum - Parrot's feather & Yes \\
\hline 25 & $7=$ & Nymphoides aquatica - Banana plant & No \\
\hline 20 & $12=$ & Anubias sp. & No \\
\hline 20 & $12=$ & Cabomba caroliniana - Fanwort & Yes \\
\hline 20 & $12=$ & Chamaedorea elegans - Bella palm & No \\
\hline 20 & $12=$ & Echinodorus osiris - Melon sword & No \\
\hline 20 & $12=$ & Hygrophilia difformis - Water wisteria & No \\
\hline 20 & $12=$ & Pilea cadierei - Aluminum plant & No \\
\hline 20 & $12=$ & Pistia stratiotes - Water lettuce & No \\
\hline 20 & $12=$ & Rotala indica $(=$ Rotala rotundifolia $)$ & No \\
\hline
\end{tabular}

Sixty-six plant taxa from 25 families were identified in our survey (Table 2). The mean number of plants recorded per store was $8.2($ s.d. $=5.2)$. Based on overwintering ability, eight plant species were recorded that could potentially survive in the Great Lakes. Of these, two (Vallisneria americana and Ceratophyllum demersum) are native to the Great Lakes. Another, Cabomba caroliniana, is a non-indigenous species that has already invaded the Great Lakes (Mills et al. 1993). The remaining four plant species were considered potential invaders: Hygrophila polysperma (Indian hygrophila), Myriophyllum aquaticum (parrot's feather), Myriophyllum heterophyllum (variable water milfoil), and Egeria densa (anacharis, egeria).

\section{Live food trade}

We recorded 14 fish species from eight families in live fish markets from Ontario and Québec (Table 3). Eight of the 14 species were native to the Great Lakes, and 
Table 3. Frequency of occurrence (\%), minimum temperature requirements and names used by store proprietors of freshwater fish species recorded from six live fish markets near Lakes Erie and Ontario. Species native to the Great Lakes are marked with an asterisk. Fish are ordered from most to least commonly occurring.

\begin{tabular}{|c|c|c|c|}
\hline Species name & $\begin{array}{l}\text { Occurrence } \\
(\%)\end{array}$ & $\begin{array}{l}\text { Minimum } \\
\text { temp. }\left({ }^{\circ} \mathrm{C}\right)\end{array}$ & Store name \\
\hline Oreochromis spp. - Tilapia & 100 & 8 & $\begin{array}{l}\text { Black tilapia, } \\
\text { white tilapia }\end{array}$ \\
\hline Aristichthys nobilis - Bighead carp & 67 & 4 & Bighead \\
\hline Ameiurus melas - Black bullhead* & 50 & 3 & Bluehead, bullhead \\
\hline Amia calva - Bowfin* & 50 & 0 & Dogfish, godfish, codfish \\
\hline Ctenopharyngodon idella - Grass carp & 50 & 0 & $\begin{array}{l}\text { Chinese buffalo, } \\
\text { china cardfish }\end{array}$ \\
\hline Ictalurus punctatus - Channel catfish* & 50 & 3 & Catfish, gatfish \\
\hline Anguilla rostrata - American eel* & 33 & 4 & Eel \\
\hline Cyprinus carpio - Common carp & 33 & 3 & $\begin{array}{l}\text { German gard, } \\
\text { carp fish }\end{array}$ \\
\hline Micropterus salmoides - Largemouth bass* & 33 & 5 & Green bass \\
\hline Morone saxatilis - Striped bass & 33 & 3 & Sea bass \\
\hline Ambloplites rupestris - Rock bass* & 17 & 5 & Green bass \\
\hline Morone americana - White perch & 17 & 0 & Bass \\
\hline Perca flavescens - Yellow perch* & 17 & 0 & Sun bass \\
\hline Pomoxis nigromaculatus - Black crappie* & 17 & 0 & Flower bass \\
\hline
\end{tabular}

may have been collected in the vicinity of the markets. Bighead carp, tilapia, common carp, grass carp, white bass and striped bass were evaluated further. Tilapia, likely comprising several Oreochromis species, was eliminated because minimum temperature requirements $\left(<5.5^{\circ} \mathrm{C}\right)$ were not met (Table 3$)$. The remaining five fish have invasion histories. Of these, the common carp and white bass are non-indigenous species that have already established widely in the Great Lakes (Mills et al. 1993), and their presence provides confidence in our model. Our model identified three fish species, two Cypriniformes and one Perciforme, as potential future invaders: bighead carp, grass carp and striped bass.

Using the model developed by Kolar and Lodge (2002; Figure 1b), common carp, striped bass and white perch are predicted to succeed if introduced to the Great Lakes, of which common carp and white perch have already invaded. Bighead and grass carp are slow growing ( $<68.5 \%$ of growth at 2 years) and failed based on the number of dietary items, while tilapia was fast growing ( $>68.5 \%$ growth at 2 years) and failed based on temperature requirements.

\section{Discussion}

\section{Aquarium trade}

The risk posed by aquarium release has already been demonstrated in the Great Lakes; this vector has been implicated in 10 species invasions $(\sim 6 \%$ of all 
documented invasions) in the basin (Mills et al. 1993). Another signal that this vector is active is the periodic capture of aquarium fishes such as pacu (Colossoma spp. and Piaractus spp.) and red-bellied piranha (Serrasalmus natterreri), which apparently cannot establish in the Great Lakes because of temperature constraints (Leach 2003).

We recorded 308 freshwater fish species from the 20 stores visited. By comparison, Ramsey (1985) recorded at least 582 fish species imported into the United States in October 1971, and proposed that thousands of fish species were utilized by the aquarium trade. A 1992 survey identified 730 imported fish species in the same industry (Chapman et al. 1997). However, Chapman (2000) noted that only 150 species in 30-35 families are in demand and account for the bulk of trading. We acknowledge, therefore, that the ornamental fish species recorded in our survey may not represent the full complement available in the Great Lakes region.

Goldfish were the most frequently occurring fish recorded in our survey, followed by bettas, guppies and neon tetras. Our results are similar to the most popular fish as measured from United States importation records used by Ramsey (1985) and Chapman et al. (1997). However, there is also variation between our measure of popularity and theirs. For example, goldfish, most popular in our survey, was ranked as 35th most popular by Ramsey (1985), while koi carp, fifth in our survey, are not listed by either author. One reason for this discrepancy may be the importance of aquaculture of ornamental fish within the United States, particularly Florida (Chapman 2000). Secondly, some variation may be due to the timing of sampling in the respective studies. Both Ramsey (1985) and Chapman et al. (1997) relied on importation records from a single month, October 1971 and October 1992, respectively. Cardinal tetra, for example, is collected seasonally in the wild, and survey timing could therefore under- or over-estimate overall volume (Chapman et al. 1997). One reason we may have underestimated popularity of some fish is due to many stores having a number of varieties of some species, for example, the platties, swordtails and mollies. Nevertheless, without obtaining sales records for each store, we believe our survey provides better estimates of species' popularities within the Great Lakes basin than prior importation records. Aside from popularity, an additional factor that may play a role in selection for release is the ability of a fish to grow to sizes too large to be confined in an aquarium or too territorial to be kept with other species, which might explain introductions of piranhas and pacus in the Great Lakes and neighboring regions.

Based on temperature tolerances, only nine of the 308 ornamental fish species could potentially survive winter temperatures in the Great Lakes. Most fishes sold in the aquarium trade are native to tropical regions of the world, and cannot tolerate temperatures below $18^{\circ} \mathrm{C}$ (Chapman 2000). Bluespotted sunfish, although believed by Werner (1972) to be an aquarium release into the Great Lakes, was not recorded in our survey. Mills et al. (1993) identified bait bucket release as an alternative vector for this species.

Our model predicted three fish species as potential invaders of the Great Lakes. Misgurnus anguillicaudatus (Oriental weatherfish) has established in the Shiawassee River system, Michigan, although its current range is highly restricted and 
it has not been reported from the Great Lakes proper (Schultz 1960; Mills et al. 1993). This species established after escape from an aquarium supply facility (Schultz 1960; Mills et al. 1993). Using thermal tolerance testing, Logan et al. (1996) documented that M. anguillicaudatus can survive at $2{ }^{\circ} \mathrm{C}$, and the Michigan population is able to survive ambient winter conditions (Schultz 1960). Although recorded from only $15 \%$ of the stores initially surveyed, two stores previously surveyed were later found to stock this fish. Based on our predictive model, this species could be spread well beyond its current distribution through aquarium introductions.

Misgurnus fossilis (weather loach) was present in $10 \%$ of the stores surveyed. This species survives at temperatures as low as $4.3^{\circ} \mathrm{C}$ in Germany, and is able to undergo winter dormancy (Meyer and Hinrichs 2000). Non-indigenous populations have been established in Italy (Bianco and Ketmaier 2001), Spain and Croatia (FAO 1997). However, because this fish was not commonly sold in aquarium stores, we classify it as having a low chance of invading the Great Lakes.

Tanichthys albonubes (white cloud mountain minnow) was found in $85 \%$ of the stores visited, and has established non-indigenous populations in Colombia (Welcomme 1988) and Madagascar (Stiassny and Raminosoa 1994). Its preferred temperature range is between 18 and $22^{\circ} \mathrm{C}$, although it can tolerate temperatures as low as $5^{\circ} \mathrm{C}$ (Froese and Pauly 2002). The popularity of this fish is apparently high, as it was the ninth most abundant fish imported into the United States in October 1971 (Ramsey 1985). Based on its ability to tolerate low temperatures, its invasion history, and high occurrence frequency, the probability of this fish invading the Great Lakes is high. However, this species has never been reported as either introduced or established into any North American waterbody (e.g., Fuller et al. 1999; Crossman and Cudmore 1999c), and successful introductions elsewhere have all occurred in tropical areas.

As with our model, Kolar and Lodge's (2002) model predicted goldfish, koi carp and oriental weatherfish as invaders. The remaining five species predicted by their model to be successful (clown loach, red tail botia, arrowana, giant snakehead and ghost catfish) have slow growth rates and hence passed down the left side of their predictive tree (see Figure 1b). Temperature requirements were therefore not considered using their model for these species, and none are likely to survive based on this factor. We propose that our derivation of Ricciardi and Rasmussen's (1998) model may have greater utility in identifying successful invaders from the aquarium industry.

Of the mollusks intentionally sold in the aquarium trade, Oriental mystery snail (Cipangopaludina chinensis) was the only species predicted to survive Great Lakes winter temperatures, and has been recorded as isolated populations in Lake Erie and the upper St. Lawrence River (Clarke 1981; Mills et al. 1993). Although this species was recorded from only one store, continued sale provides the potential for this species to spread more widely. The presence of additional taxa associated with macrophytes and substrates not intended for sale indicates that movement and introduction of many freshwater mollusks could also occur as contaminants in purchases of other taxa (e.g., macrophytes). Of the species we identified that were not in- 
tentionally sold, Melanoides tuberculata was predicted by MacIsaac (1999) to be a potential invader of Lake Erie. However, our model predicts that this species would fail establishment due to intolerance to cold temperatures (e.g., Duggan 2002).

Four macrophyte species were predicted as potential invaders of the Great Lakes from the aquarium trade. Hygrophila polysperma was present in $25 \%$ of the stores visited. This plant grows primarily rooted and submersed, and can also grow emersed in shallow water areas (Cuda and Sutton 2000). This species is native to India and Malaysia, and has established populations in Florida and Texas, with reported cases from Virginia (Langeland and Burks 1998; Benson et al. 2001). Although it prefers warm waters, it can apparently tolerate temperatures of $4{ }^{\circ} \mathrm{C}$ (Kasselmann 1995). Myriophyllum aquaticum also was found in $25 \%$ of the stores surveyed. It is native to South America, and has been widely introduced in the United States via the aquarium and water garden trade (Les and Mehrhoff 1999; Benson et al. 2001). It is able to survive winter freezes in northern California (Les and Mehrhoff 1999). Egeria densa was found in 35\% of the stores surveyed. Apparently introduced to North America as an aquarium escapee (Muenscher 1944), this species is established in states including Oregon, New York, Maryland and Connecticut (Les and Mehrhoff 1999), and is therefore likely capable of surviving in the Great Lakes. It over-winters vegetatively as short green shoots, which can survive at $1{ }^{\circ} \mathrm{C}$ under $15 \mathrm{~cm}$ of ice (Catling and Wojtas 1986; Champion and Tanner 2000). Because each of these macrophytes can tolerate winter conditions in regions of the Great Lakes, and appear to be commonly sold in aquarium stores, we view them as representing a high invasion risk. One other plant appears to pose a lower invasion risk. Myriophyllum heterophyllum was present in $10 \%$ of the stores surveyed. It is native to the east coast of North America, as far north as Virginia. It is currently spreading through the New England states, where buds enable over-wintering (Les and Mehrhoff 1999).

There are two reasons to expect invasion threats from the aquarium industry to increase with time. Firstly, the pool of potential invaders is ever expanding as the industry searches for new, potentially popular species to market. Secondly, because most aquarium species are of tropical and subtropical origin, the probability of their establishment in the Great Lakes will increase with climatic warming. A series of invasions by a dozen warmwater fishes has already taken place in the basin over the past several decades and more are predicted to occur as thermal barriers are shifted (Mandrak 1989).

\section{Live food markets}

We recorded 14 freshwater species from live fish markets in Ontario and Québec, Canada. Common names provided on the tanks by proprietors rarely gave an indication of the true identity of species, as was also noted by Crossman and Cudmore (1999b); for example, for Pomoxis nigromaculatus, 'flower bass' is perhaps a more marketable name than the correct label 'black crappie'. Three species were predicted by our model to potentially invade the Great Lakes. Bighead carp (Aristichthys 
nobilis) was recorded in four of the six stores surveyed. Based on wholesale records, Goodchild (1999a) estimated bighead carp comprised 52\% of the weight of all freshwater fish in the live trade in Ontario. This species may survive at temperatures as low as $4{ }^{\circ} \mathrm{C}$, and has been introduced widely from southern and central China, particularly to Europe, for aquaculture (FAO 1997; Fuller et al. 1999). It has also been introduced into a number of American states and has escaped from fish farms to form reproducing populations in the Mississippi river basin (Fuller et al. 1999). From this drainage, bighead carp may potentially enter the Great Lakes through the Chicago Sanitary and Shipping Canal into Lake Michigan (Moy 2001; Taylor et al. 2003). An electrical fish barrier currently restricts passage of these fish into Lake Michigan, and further methods to restrict entry through this canal are being examined (e.g., sound and bubble barriers; Taylor et al. 2003). The sale of these fish in live fish markets around the Great Lakes provides additional opportunities for introduction to the basin. Individual, live bighead carp have been recovered on three separate occasions in western Lake Erie in recent years, hundreds of kilometers from the nearest wild populations in the Mississippi basin.

The grass carp (Ctenopharyngodon idella) was recorded in half of the stores visited, and Goodchild (1999a) estimated this species comprised 9\% of the weight of all freshwater fish sold in the live trade in Ontario. This species is native to Eastern Asia (Fuller et al. 1999), and has been recorded from Lakes Michigan, Erie, Huron and St. Clair, although apparently is not yet established in these systems (Goodchild 1999b). A single individual was recovered at the mouth of the Don River, Lake Ontario, near Toronto, Ontario during an autumn 2003 electro-fishing assessment of fish communities. Additional records have been noted in almost every US state (Fuller et al. 1999). Grass carp can tolerate temperatures between 0 and $38^{\circ} \mathrm{C}$ (Froese and Pauly 2002), and therefore poses an invasion risk.

Morone saxatilis (striped bass) was present in $33 \%$ of the stores surveyed. It is native to the Atlantic coast of North America and St. Lawrence River as far west as Montréal (Fuller et al. 1999). Non-indigenous occurrences have been reported from Lakes Huron, Erie and Ontario (Goodchild 1999b); however, successful establishment has apparently not yet occurred in the Great Lakes. This species has an invasion history in South Africa, western Europe and many areas of North America (Welcomme 1988; Fuller et al. 1999), and can tolerate temperatures as low as $3{ }^{\circ} \mathrm{C}$ (Froese and Pauly 2002). However, based on wholesaler records, the species seems relatively unimportant in the Ontario live fish trade, comprising $<1 \%$ of the weight of freshwater fish sold, although its importance is apparently increasing (Goodchild 1999b). It occurred in only a third of the markets we surveyed, and thus represents a lower risk of invasion.

Based on the live fish industry in Ontario, Goodchild (1999a) identified grass carp, bighead carp, black carp, striped bass, and tilapia as invasion threats. Based on our model, neither tilapia nor black carp pose an invasion risk from live fish markets, the former because of its thermal intolerance, the latter because of a lack of opportunity. Eventually black carp may invade the Great Lakes, because it has recently been found in an Illinois lake, far north of its former limit, although it is unlikely to become established elsewhere owing to the triploid (i.e., sterile) con- 
Table 4. Potential aquarium species and live fish market species based on our model that pose a threat to the Great Lakes.

\begin{tabular}{lll}
\hline & High probability of establishment & Low probability of establishment \\
\hline Aquarium fish & $\begin{array}{l}\text { Misgurnus anguillicaudatus } \\
\text { Tanichthys albonubes }\end{array}$ & Misgurnus fossilis \\
Aquarium plants & $\begin{array}{l}\text { Hygrophila polysperma } \\
\text { Myriophyllum aquaticum } \\
\text { Egeria densa }\end{array}$ & Myriophyllum heterophyllum \\
Live food fish & $\begin{array}{l}\text { Aristichthys nobilis } \\
\text { Ctenopharyngodon idella }\end{array}$ & Morone saxatilis \\
\hline
\end{tabular}

stitution of the fish (Chick et al. 2003). Using the model developed by Kolar and Lodge (2002; Figure 1b), common carp, striped bass and white perch were predicted as potential invaders to the Great Lakes. Common carp and white perch have already established populations in the Great Lakes.

\section{Conclusions}

In summary, our surveys demonstrate commercial trade of a variety of nonindigenous species that could survive in the Great Lakes (Table 4). Species of particular concern (oriental weatherfish, white cloud mountain minnow, dwarf hygrophila, parrot's feather, egeria, bighead carp, grass carp) have appropriate thermal tolerances, invasion histories, and opportunities for introduction - all of the essential components seemingly necessary to become established in the Great Lakes. The identification of these high-risk species indicates the need to address the issue of live fish markets and the aquarium industry, in addition to other vectors of invasion, in the Great Lakes and other aquatic ecosystems. We recommend the erection of trade restrictions regarding sale, importation or breeding of high-risk species in areas where these have potential for establishing populations.

\section{Acknowledgments}

We thank A. Matos, V. Rixon, Y. Rixon, D. Gray, J. Muirhead, D. Roy, S. Bailey, R. Colautti, L. Jones, A. Jökela and C. van Overdijk for valuable assistance, comments and advice. We express our gratitude to the anonymous reviewers for improving the manuscript. We acknowledge financial support from NSERC (Canada) to A.R. and H.J.M.

\section{References}

Baensch H.A. and Riehl R. 1996. Aquarium Atlas. Mergus Publishing, Germany.

Benson A.J., Fuller P.L. and Jacono C.C. 2001. Summary report of non-indigenous aquatic species in U.S. fish and wildlife Service region 4. U.S. Geological Survey Florida Caribbean Science Center, Florida. 
Bianco P.G. and Ketmaier V. 2001. Anthropogenic changes in the freshwater fish fauna of Italy, with reference to the central region and Barbus graellsii, a newly established alien species of Iberian origin. Journal of Fish Biology 59 (Suppl. A): 190-208.

Catling P.M. and Wojtas W. 1986. The waterweeds (Elodea and Egeria, Hydrocharataceae) in Canada. Canadian Journal of Botany 64: 1525-1541.

Champion P.D. and Tanner C.C. 2000. Seasonality of macrophytes and interaction with flow in a New Zealand lowland stream. Hydrobiologia 441: 1-12.

Chapman F.A. 2000. Ornamental fish culture, freshwater. In: Stickney R.R. (ed) Encyclopedia of Aquaculture. John Wiley and Sons, New York, pp. 602-610.

Chapman F.A., Fitz-Coy S., Thunberg E.M. and Adams C.M. 1997. United States of America trade in ornamental fish. Journal of the World Aquaculture Society 28: 1-10.

Chick J.H., Maher R.J., Burr B.M. and Thomas M.R. 2003. First black carp captured in the U.S. Science 300: 1876

Clarke A.H. 1981. The Freshwater Molluscs of Canada. National Museum of Natural Sciences, Ottawa, Canada.

Courtenay Jr. W.R. 1999. Aquariums and water gardens as vectors of introduction. In: Claudi R. and Leach J.H. (eds) Nonindigenous Freshwater Organisms: Vectors, Biology, and Impacts. Lewis Publishers, Boca Raton, Florida, pp. 127-128

Courtenay Jr. W.R. and Stauffer Jr. J.R. 1990. The introduced fish problem and the aquarium fish industry. Journal of the World Aquaculture Society 21: 145-159.

Courtenay Jr. W.R. and Taylor J.N. 1986. Strategies for reducing risks from introductions of aquatic organisms: a philosophical perspective. Fisheries 11: 34-38.

Crossman E.J. 1984. Introduction of exotic fishes into Canada. In: Courtenay Jr. W.R. and Stauffer Jr. J.R. (eds) Distribution, Biology, and Management of Exotic Fishes. Johns Hopkins University Press, Baltimore, Maryland, pp. 78-101.

Crossman E.J. and Cudmore B.C. 1999a. Summary of North American fish introductions through the aquarium/horticulture trade. In: Claudi R. and Leach J.H. (eds) Nonindigenous Freshwater Organisms: Vectors, Biology, and Impacts. Lewis Publishers, Boca Raton, Florida, pp. 129-134.

Crossman E.J. and Cudmore B.C. 1999b. Summary of North American introductions of fish through the aquaculture vector and related human activities. In: Claudi R. and Leach J.H. (eds) Nonindigenous Freshwater Organisms: Vectors, Biology, and Impacts. Lewis Publishers, Boca Raton, Florida, pp. $297-$ 304.

Crossman E.J. and Cudmore B.C. 1999c. Summary of fishes intentionally introduced in North America. In: Claudi R. and Leach J.H. (eds) Nonindigenous Freshwater Organisms: Vectors, Biology, and Impacts. Lewis Publishers, Boca Raton, Florida, pp. 99-112.

Cuda J.P. and Sutton D.L. 2000. Is the aquatic weed Hygrophila, Hygrophila polysperma (Polemoniales: Acanthaceae), a suitable target for classical biological control? In: Spencer N.R. (ed) Proceedings of the $\mathrm{X}$ International Symposium on Biological Control of Weeds. Montana State University, Bozeman, Montana, pp. 337-348.

Duggan I.C. 2002. First record of a wild population of the tropical snail Melanoides tuberculata in New Zealand natural waters. New Zealand Journal of Marine and Freshwater Research 36: 825-829.

FAO 1997. FAO Database on Introduced Aquatic Species, FAO, Rome, Italy.

Froese R. and Pauly D. (eds) 2002. FishBase. World Wide Web electronic publication. www.fishbase.org. Fuller P.L., Nico L.G. and Williams J.D. 1999. Non-indigenous Fishes Introduced into Inland Waters of the United States. American Fisheries Society, Special Publication 27, Bethesda, Maryland.

Goodchild C.D. 1999a. A Risk Analysis of the Live Food Fish Industry in Ontario. Ontario Ministry of Natural Resources.

Goodchild C.D. 1999b. Non-indigenous Freshwater Fish Utilized in the Live Food Fish Industry in Ontario: A Summary of Information. Ontario Ministry of Natural Resources.

Groves R.H. and Burdon J.J. (eds) 1986. Ecology of Biological Invasions. Cambridge University Press, Cambridge, UK

Hiscock P. 2003. Encyclopedia of Aquarium Plants. Barron's Educational Series Inc., New York. Jenkins P.T. 1996. Free trade and exotic species introductions. Conservation Biology 10: 300-302. 
Kasselmann C. 1995. Aquarienpflanzen. Egen Ulmer GMBH and Co., Stuttgart, Germany.

Kesminas V., Virbickas T. and Klimas R. 1994. Estimation of fish production in the polluted Musa River, Lithuania. Aqua Fennica 24: 21-27.

Kolar C.S. and Lodge D.M. 2002. Ecological predictions and risk assessment for alien fishes in North America. Science 298: 1233-1236.

Langeland K.A. and Burks K.C. 1998. Identification and biology of non-native plants in Florida's natural areas, IFAS Publication SP 257. University of Florida, Gainesville, Florida.

Leach J.H. 2003. Unusual invaders of Lake Erie. Point Pelee Natural History News 3: 1-5.

Les D.H. and Mehrhoff L.J. 1999. Introduction of non-indigenous aquatic vascular plants in southern New England: a historical perspective. Biological Invasions 1: 281-300.

Logan D.J., Bibles E.L. and Markle D.F. 1996. Recent collections of exotic aquarium fishes in the freshwaters of Oregon and thermal tolerance of oriental weatherfish and pirapatinga. California Fish and Game 82: 66-80.

MacIsaac H.J. 1999. Biological invasion in Lake Erie: past, present and future. In: Munawar M., Edsall T. and Munawar I.F. (eds) State of Lake Erie - Past, Present and Future. Backhuys Publishers, Leiden, The Netherlands, pp. 305-322.

MacIsaac H.J., Grigorovich I.A. and Ricciardi A. 2001. Reassessment of species invasions concepts: the Great Lakes basin as a model. Biological Invasions 3: 405-416.

Mackie G.L. 1999. Mollusk introductions through aquarium trade. In: Claudi R. and Leach J.H. (eds) Nonindigenous Freshwater Organisms: Vectors, Biology, and Impacts. Lewis Publishers, Boca Raton, Florida, pp. 135-150.

Mandrak N.E. 1989. Potential invasion of the Great Lakes by fish species associated with climatic warming. Journal of Great Lakes Research 15: 306-316.

McCosker J.E. 1989. Freshwater eels (family Anguillidae) in California: current conditions and future scenarios. California Fish and Game 75: 4-10.

Meyer L. and Hinrichs D. 2000. Microhabitat preferences and movements of the weatherfish, Misgurnus fossilis, in a drainage channel. Environmental Biology of Fishes 58: 297-306.

Mills D. 1993. Aquarium Fish. Dorling Kindersley Limited, London.

Mills E.J., Leach J.H., Carlton J.T. and Secor C.L. 1993. Exotic species in the Great Lakes: a history of biotic crises and anthropogenic introductions. Journal of Great Lakes Research 19: 1-54.

Moy P. 2001. Chicago sanitary ship canal. Wisconsin Natural Resources Magazine. June 2001.

Muenscher W.C. 1944. Aquatic Plants of the United States. Comstock, Ithaca, New York.

Myers J.H., Simberloff D., Kuris A.M. and Carey J.R. 2000. Eradication revisited: dealing with exotic species. Trends in Ecology and Evolution 15: 316-320.

Page L.M. and Burr B.M. 1991. Freshwater Fishes: North America to North of Mexico. Houghton Mifflin Company, Boston, Massachusetts.

Ramsey J.S. 1985. Sampling aquarium fishes imported by the United States. Journal of the Alabama Academy of Science 56: 220-245.

Reichard S.H. and Hamilton C.W. 1997. Predicting invasions of woody plants introduced into North America. Conservation Biology 11: 193-203.

Ricciardi A. and MacIsaac H.J. 2000. Recent mass invasion of the North American Great Lakes by PontoCaspian species. Trends in Ecology and Evolution 15: 62-65.

Ricciardi A. and Rasmussen J.B. 1998. Predicting the identity and impact of future biological invaders: a priority for aquatic resource management. Canadian Journal of Fisheries and Aquatic Sciences 55: 1759-1765.

Rouget M. and Richardson D.M. 2003. Inferring process from pattern in plant invasions: a semi mechanistic model incorporating propagule pressure and environmental factors. American Naturalist 162: $713-724$.

Schultz E.E. 1960. Establishment and early dispersal of a loach, Misgurnus anguillicaudatus (Cantor), in Michigan. Transactions of the American Fisheries Society 89: 376-377.

Severinghaus L.L. and Chi L. 1999. Prayer animal release in Taiwan. Biological Conservation 89: 301-304. 
Stiassny M.L.J. and Raminosoa N. 1994. The fishes of the inland waters of Madagascar. Biological diversity of African fresh- and brackish water fishes. Geographical overviews. Annales Musée Royale de l'Afrique Centrale, Zoologiques 275: 133-149.

Taylor R.M., Pegg M.A. and Chick J.H. 2003. Some observations on the effectiveness of two behavioral fish guidance systems for preventing the spread of bighead carp to the Great Lakes. Aquatic invaders: the digest of national aquatic nuisance species clearinghouse 14: 1-5.

Welcomme R.L. 1988. International Introductions of Inland Aquatic Species. FAO Fisheries Technical Paper 294.

Werner R.G. 1972. Bluespotted sunfish, Enneacanthus gloriosus, in the Lake Ontario drainage. Copeia 1972: 878-879.

Williamson M. 1996. Biological Invasions. Chapman \& Hall, London. 